\title{
Extent and structure of genetic diversity in a collection of the tropical multipurpose shrub legume Cratylia argentea (Desv.) O. Kuntze as revealed by RAPD markers
}

\author{
Meike S. Andersson* \\ Biodiversity International \\ c/o CIAT, A.A. 6713 \\ Cali, Colombia \\ Tel: 572 4450048. Ext. 113 \\ Fax: 5724450069 \\ E-mail: m.andersson@cgiar.org
}

Rainer Schultze-Kraft

Institute of Plant Production and Agroecology in the Tropics and Subtropics

University of Hohenheim

D-70593 Stuttgart, Germany

Tel: 4971145923538

Fax: 4971145924207

E-mail: rsk@uni-hohenheim.de

\section{Michael Peters}

International Center for Tropical Agriculture

$$
\text { A.A. } 6713
$$

Cali, Colombia

Tel: 572 4450000. Ext. 3267

Fax: 5724450073

E-mail: m.peters-ciat@cgiar.org

\section{Myriam C. Duque}

International Center for Tropical Agriculture A.A. 6713

Cali, Colombia

Tel: 572 4450000. Ext. 3487

Fax: 5724450073

E-mail:mc.duque@cgiar.org

\section{Gerardo Gallego}

International Center for Tropical Agriculture

$$
\text { A.A. } 6713
$$

Cali, Colombia

Tel: 572 4450000. Ext. 3265

Fax: 5724450073

E-mail: g.gallego@cgiar.org

Websites: http://www.uni-hohenheim.de http://www.ciat.cgiar.org

Keywords: agroforestry, molecular markers, MPT (multipurpose shrubs and trees), tropics.

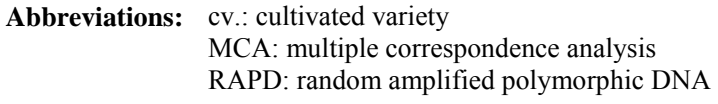

The tropical multipurpose shrub legume Cratylia argentea is well adapted to acid soils of low to medium fertility and has excellent drought-tolerance. Due to its high nutritive value it is particularly suited as forage for dry-season supplementation. A collection of 47 C. argentea accessions in a collection, derived from seed

*Corresponding author 
replicating of original accessions with differing geographic origin and morphological and agronomic characteristics was investigated using molecular markers (RAPD (random amplified polymorphic DNA)). Genetic diversity $\left(H_{T}=0.145\right)$ in the collection was low, with $30 \%$ of differentiation among groups and high genetic similarity among accessions ( $G S=0.805)$. Within-accession variability was high. One taxonomic mismatch and five possible duplicate accessions were identified. Our results suggest that the genetic diversity in the $C$. argentea accessions studied is relatively homogeneously distributed, indicating the likelihood of extensive outcrossing. The genetic diversity of original accessions should be assessed to determine if outcrossing has occurred during or before ex situ storage. This might also support any decision on whether accessions should be bulked rather than maintaining them individually.

Cratylia argentea (Desv.) O. Kuntze (syn. C. floribunda Benth., Dioclea argentea Desv.) is a drought-tolerant tropical multipurpose shrub legume with high potential for animal nutrition, particularly for dry season supplementation and silage, due to its high nutritive value (Argel and Lascano, 1998). The leafy shrub usually reaches a height of 1.5 to $3 \mathrm{~m}$ and has the potential to remain green and productive during dry seasons up to seven months. It is well adapted to acid soils of low to medium fertility and to elevations up to 1200 m.a.s.l.

Cratylia argentea contains only traces of tannins and its nutritive value is higher than that of most other shrub legumes adapted to acid soils (Schultze-Kraft, 1996). The species shows excellent regrowth after cutting and can be used as forage, soil cover, mulch and green manure (Argel and Lascano, 1998; Lascano et al. 2002). It is a valuable protein source in livestock production systems, particularly during the dry season, both in cut-and-carry (fresh fodder and silage) and in grazing systems (Argel and Lascano, 1998; Lascano et al. 2002). C. argentea can be easily propagated by seed, whereas vegetative propagation was unsuccessful (Pizarro et al. 1996).

The genus Cratylia is native to South America where it occurs south of the Amazon river, from western Peru to the state of Ceará in Brazil. The taxonomic delimitations within the genus are not yet defined. According to Queiroz and Coradin (1996) there are five species distinguished based on morphological characteristics and geographical distribution. Four of them, C. mollis Mart. ex Benth., C. hypargyraea Mart. ex Benth., C. bahiensis L.P. Queiroz and C. intermedia (Hassl.) L.P. Queiroz and R. Monteiro, are restricted to Brazil. The distribution range of $C$. argentea extends from western Peru to Bolivia and Brazil. The species occurs in a broad range of biogeographical regions such as the Cerrado, Caatinga, Yungas and Amazon provinces.
Collections of C. argentea are held in Brazil by Embrapa Recursos Genéticos e Biotecnologia, Brasília and Embrapa Cerrados, Planaltina (45 and 48 accessions, respectively), and by the International Center for Tropical Agriculture (CIAT), Cali, Colombia (57 accessions). However, a reconciled total collection probably comprises not more than 50 different accessions. The germplasm was mostly collected during general wild-legume collecting missions, i.e., where the target was a wide range of species. Depending on topography and soil variability, not only the distance between general legume sampling sites in these missions was variable but, subsequently, also the distance between individual C. argentea accessions. The accessions were collected in a diversity of environments and broadly represent the natural distribution of the species.

Agronomic and morphological evaluations across a range of sites in tropical America concentrated on a collection of 11 accessions (Schultze-Kraft, 1996) and as a result, acommercial variety consisting of a mixture of accessions CIAT 18516 and CIAT 18668 was released in Costa Rica as cv. (cultivated variety) Veraniega and in Colombia as cv. Veranera (Lascano et al. 2002). Recently, the agronomic and morphological diversity in an expanded collection of 38 accessions was described by Andersson et al. (2006a).

The aim of the present study was to complement the latter variability assessment by a molecular marker approach. The specific objectives were to assess and describe the genetic diversity (a) within a collection of 47 accessions, and (b) within accessions, and (c) identify possible duplicates and taxonomic mismatches. When choosing a molecular marker technique, one should not only consider the particular objective(s) of the study, but also the technical requirements and the cost and time investments implied. In the present case, random amplified polymorphic DNA (RAPD) markers were chosen since they are an effective and relatively inexpensive technique and do not require any prior sequence information (Jones et al. 1997; Chenuil, 2006). These dominant neutral markers sample the genome randomly generating multiple numbers of amplifiable polymorphic fragments, and can be applied to a wide range of plant and animal taxa. They are especially useful for distinguishing individuals, cultivars or accessions, and allow the quantification of similarities or differences (Jones et al. 1997; Parker et al. 1998).

\section{MATERIALS AND METHODS}

\section{Plant material and DNA extraction}

The 47 Cratylia argentea accessions used in this study were collected mainly in the Brazilian states of Mato Grosso and Goiás in three collection missions in 1984, 1993 and 1995 (Figure 1, Table 1). Accessions are bulk samples of three plants per accession, representing populations at their respective collection sites. Two accessions (CIAT 18672 and CIAT 18957) were collected at the northern limit of the natural distribution range of the 
species in the Brazilian states of Pará and Tocantins, south of the Amazon river $\left(03^{\circ} 45^{\prime} \mathrm{S}\right.$ and $06^{\circ} 30^{\prime} \mathrm{S}$, respectively). The only non-erect but prostrate and strongly climbing accession (CIAT 22397 'Yapacaní') was collected in Santa Cruz, Bolivia. Cratylia mollis CIAT 7940 was included as additional reference to validate the genetic assessment of $C$. argentea, expecting the genetic similarity among $C$. argentea accessions to be greater than between accessions of $C$. argentea and C. mollis, another drought tolerant legume shrub native to the dry Caatinga of north-eastern Brazil (Queiroz and Coradin, 1996).

At CIAT, the entire C. argentea collection is replicated every 7 to 10 years. Accordingly, the plant material used in this study has undergone one (accessions collected between 1993 and 1998) or two (accessions collected in 1984) multiplication cycles, respectively (A. Ciprián, CIAT GRU, personal communication 2006). Seedlings were raised in the greenhouse and transplanted to the field at the CIATQuilichao Experimental Station (Cauca department, Colombia; $03^{\circ} 06^{\prime} \mathrm{N}, 76^{\circ} 31^{\prime} \mathrm{W}$; 990 m.a.s.l). Young leaves were harvested in the field just before reaching fully developed size. For the determination of genetic variability among accessions, bulked samples were taken from three individual plants per accession. For the assessment of within-accession genetic variability, leaves were harvested separately from ten individual plants of each of five accessions (CIAT 18516, CIAT 18668, CIAT 18674, CIAT 22408 and CIAT 22409). Samples were macerated in liquid nitrogen and total genomic DNA extracted from $50 \mathrm{mg}$ tissue using a small-scale DNA extraction method (Qiagen DNeasy ${ }^{\circledR}$ Plant Mini Extraction Kit, Qiagen Inc., Valencia, CA, USA) with minor modifications: 600 instead of $400 \mu \mathrm{l}$ Buffer AP1, 2 instead of $4 \mu \mathrm{l}$ RNAse, and 150 instead of $130 \mu \mathrm{l}$ Buffer AP2. DNA was quantified by means of a DyNA Quant ${ }^{\mathrm{TM}} 200$ fluorometer (Hoefer Scientific Instruments, San Francisco, CA, USA) and diluted to a final concentration of $5 \mathrm{ng} \mathrm{DNA} / \mu \mathrm{l}$.

\section{RAPD markers}

The protocol for RAPD analysis was as described in Andersson et al. (2006b), with the volume of the final reaction $(25 \mu \mathrm{l})$ being composed of 1 X PCR buffer $(50 \mathrm{mM}$ $\mathrm{KCl}, 10 \mathrm{mM}$ Tris- $\mathrm{HCl} \mathrm{pH} 8.8,0.1 \%$ Triton $\mathrm{x}-100), 2.5 \mathrm{mM}$ $\mathrm{MgCl} 2,0.2 \mathrm{mM}$ of each dNTPs, $0.2 \mu M$ primer (Series OPD, OPG, OPI and OPJ from Operon Technologies, Alameda, CA, USA), 1 U Taq DNA polymerase (Promega Corp., Madison, WI, USA) and $25 \mathrm{ng}$ of template DNA. A negative control without template DNA was included in each round of reactions. Amplifications were performed in a thermocycler (PTC-100 ${ }^{\mathrm{TM}}$, MJ Research Inc., Watertown, MA, USA) with an initial denaturing step of $5 \mathrm{~min}$ at $94^{\circ} \mathrm{C}$ followed by 40 cycles of $30 \mathrm{sec}$ at $94^{\circ} \mathrm{C}, 30 \mathrm{sec}$ at $38^{\circ} \mathrm{C}$ and $1 \mathrm{~min}$ at $72^{\circ} \mathrm{C}$ and a final extension step of $5 \mathrm{~min}$ at $72^{\circ} \mathrm{C}$. The PCR products were run on a $1.4 \%$ agarose gel at 20 $\mathrm{V} / \mathrm{cm}$ during $45 \mathrm{~min}$. The amplified DNA fragments were visualised by ethidium bromide staining $(0.5 \mu \mathrm{g} / \mathrm{ml}$ bromide in gel and buffer) under UV-light, and photographed with a Kodak digital camera DC 120 (Software Kodak Digital Science ${ }^{\mathrm{TM}}$ 1997).

\section{Data analysis}

Amplified DNA fragments were manually scored as present (1) or absent (0) for each primer, and variations in band presence were recorded as polymorphisms.

Data were converted into a similarity matrix using the Nei and Li similarity coefficient based on the proportion of shared fragments. The Nei and Li similarity coefficient (Nei and Li, 1979) calculates the genetic similarity (GS) between two samples, $i$ and $j$, with the formula $G S(i, j)=$ $2 N i j /(2 N i j+N i+N j)$, where $N i j$ is the number of bands present in both $i$ and $j, N i$ is the number of bands present in $i$ and absent in $j$, and $\mathrm{Nj}$ is the number of bands present in $j$ and absent in $i$.

Then, a similarity tree was produced by clustering the similarity matrix based on the Average Linkage UPGMA (unweighted pair group method with arithmetic averages) algorithm. The dendrogram was cut considering a cophenetic value of $0.97\left(R^{2}\right)$, which resulted in 7 groups and a level of $77 \%$ of genetic similarity. The calculation of genetic similarity and cluster analysis were performed using the NTSYS package version 2.1. In addition, multiple correspondence analysis (MCA) was performed on the original matrix to provide an additional representation of genetic similarity and to visualize the dispersion of individuals in relation to their molecular profile, based on the first three principal axes of variation. Means of genetic similarity and genetic diversity within and among groups were determined for both methods (cluster analysis and MCA) to analyse the coherence of the resulting classifications. MCA and means of genetic diversity were calculated using SAS version 8.2.

The efficiency of the RAPD primers to differentiate among accessions was evaluated by calculating the discriminatory power $\mathrm{D}_{\mathrm{L}}=1-\sum \mathrm{p}_{i}^{2}$, with $\mathrm{p}_{i}$ being the proportion of accessions carrying the $i$ th banding pattern at the $j$ th primer and calculating pi for each pattern generated by the primer (Tessier et al. 1999). $D_{L}$ is an extension of the polymorphism information content (PIC) and provides an estimate of the probability that two randomly chosen individuals show different banding patterns for the same primer, and thus are distinguishable from one another.

\section{RESULTS}

\section{RAPD profiles}

Out of the 47 oligonucleotide decamer primers initially screened with three C. argentea accessions, 17 gave smeared or faint bands and seven gave no amplification products. Fifteen primers identified high levels of polymorphism and were repeated to test for reproducibility. Out of these, six primers detected distinct, clearly resolved 
and consistently reproducible amplification products and were, therefore, selected for the amplification of RAPD sequences. They generated a total of 72 scorable fragments across the $47 \mathrm{C}$. argentea accessions and the C. mollis reference accession (Table 2). On average 11 scorable fragments were obtained per primer, ranging from six (primer OPJ 12) to 16 (primers OPG 12 and OPI 07). The band size ranged from 320 to $2900 \mathrm{bp}$. A RAPD profile generated by primer OPD 15 is shown in Figure 2.

Out of the 72 fragments detected across all analysed accessions, 68 (94\%) were polymorphic. Among C. argentea accessions, 61 fragments were detected, 56 (92\%) being polymorphic. Eleven markers generated by primers OPD 15, OPG 12, OPI 07 and OPJ 12 were unique to $C$. mollis, and five markers (all generated by primer OPI 07) were unique to C. argentea accessions. Of these, three were unique to the only non-erect $C$. argentea accession CIAT 22397 ('Yapacaní'), and the other two were found in CIAT 22399 and CIAT 22403, respectively. In addition, three markers (generated by primers OPJ 06 and OPJ 12) were common to C. mollis and 'Yapacaní', but were absent in the other C. argentea accessions. Although the two accessions CIAT 18672 and CIAT 18957 were collected at the northern limit of the natural distribution range of the species and were geographically as distant from the rest of the collection as was the Bolivian accession 'Yapacaní' (Figure 1), no fragments unique to these accessions were detected.

The discriminatory power $\left(D_{L}\right)$ of the selected primers ranged from 0.615 to 0.942 , with four primers having > $85 \%$ probability of discriminating between two accessions (Table 2). As reported by Tessier et al. (1999) our data showed that the discriminatory power of a primer does not solely depend on the number of bands and banding patterns it generates. For example, primer OPD 15, which generated nine polymorphic bands and 18 different banding patterns, had a discriminatory power of $90 \%$, whereas primer OPI 07 with more polymorphic bands (16) and a similar number of banding patterns (16) had a much lower discriminatory power $(75 \%)$.

\section{Cluster and multiple correspondence analyses}

The dendrogram based on Nei and Li genetic similarity, provides seven groups at the $77 \%$ level of genetic similarity (Figure 3). First, the C. mollis reference accession is separated, followed by the only non-erect accession 'Yapacaní' (CIAT 22397). Subsequently, two groups each containing only one accession are split: CIAT 18668 and CIAT 22389. Next, a 4-member group comprising accessions CIAT 18674, CIAT 22384, CIAT 22386 and CIAT 22401, and a single accession (CIAT 22408) are separated. The remaining 39 accessions (81\%) fall into one main cluster (Figure 3).

MCA confirms the separation of the C. mollis reference and the non-erect $C$. argentea accession 'Yapacaní' from the remaining accessions (first and second dimension, accounting for $27 \%$ and $14 \%$ of the total variation, respectively). The multiple correspondence coordinates of each of the three groups (C. mollis, 'Yapacaní' and the remaining C. argentea accessions) form the extreme points of an almost equally-sided triangle, indicating that the nonerect C. argentea accession 'Yapacaní' is genetically almost as distant from all other C. argentea accessions as is $C$. mollis. The third dimension discriminates the remaining 46 C. argentea accessions into two main and three smaller groups (Figure 4). Accession CIAT 18668 is grouped together with CIAT 22389 and CIAT 22403 (group 5 in Figure 4), and CIAT 22386 with CIAT 22387 (group 4). Accession CIAT 18674 makes up a group of its own (group $3)$. The remaining 40 accessions (83\%) fall into two main clusters, containing 28 and 12 accessions, respectively.

Geographic origin (i.e. distance) had only limited influence on the composition of the groups. In several instances, genetically similar accessions were detected from geographically very distant areas (e.g. CIAT 22373 and CIAT 22409), whereas geographically close accessions often appeared to be genetically very distant in both cluster analysis and MCA (e.g. CIAT 18675 and CIAT 22408). Here again, it was not possible to distinguish the two accessions CIAT 18672 and CIAT 18957, which were the most distant from the rest of the collection in terms of geographic distance (Figure 1). Both accessions clustered tightly together with other accessions distributed widely throughout Central Brazil, in cluster as well as in MCA.

\section{Genetic diversity and genetic similarity among and within groups}

Total genetic diversity in the sample studied here was low $\left(H_{T}=0.169\right)$, with only $30 \%$ of differentiation among groups $\left(G_{S T}=0.302\right)$ (Table 3$)$. The mean genetic similarity was high $(G S=0.776)$ and ranged from 0.388 to 0.814 among groups (Table 4) and from 0.316 to 0.947 among accessions (data not shown). When excluding the two most genetically distant accessions, 'Yapacaní' and C. mollis (groups 6 and 7, respectively), total diversity decreased to $H_{T}=0.145$, and the coefficient of gene differentiation was reduced by half to $15.2 \%$ (Table 3). Mean GS increased to 0.805 , ranging from 0.720 to 0.814 among groups (Table 4 ) and from 0.604 to 0.947 among accessions (data not shown). The genetic similarity between groups (Table 4, above diagonal) was as high as or even higher than within groups (Table 4, diagonal).

\section{Genetic diversity and genetic similarity within accessions}

To compare mean genetic diversity within and among $C$. argentea accessions, ten individual plants of each of five accessions were chosen. Total genetic diversity $H_{T}$ among these accessions was 0.180 , while mean genetic diversity within accessions $\left(H_{S}\right)$ was 0.152 , representing $84 \%$ of total genetic variation. Mean genetic similarity GS was 0.720 , 
ranging from 0.730 to 0.800 within the five accessions studied (Table 5).

\section{Possible duplicates in the collection}

If considering accessions as genetically identical when their genetic similarity $G S$ was equal to or greater than 0.95 , then all accessions were uniquely identified, indicating that the collection does not contain genetic duplicates. However, a group of possible duplicate candidates was identified (CIAT 22373, CIAT 22378, CIAT 22380, CIAT 22381 and CIAT 22411) with pairwise genetic similarities very close to this value $(G S>0.94)$.

\section{DISCUSSION AND CONCLUDING REMARKS}

In this first study of genetic diversity in Cratylia with RAPD molecular technique, the level of DNA polymorphism detected with six decamer random primers was very high $(>90 \%)$ and allowed the distinction of all accessions analysed. The high discriminatory power of the primers used ( $83 \%$ on average) indicates that the RAPD technique provides an effective tool for germplasm analysis in Cratylia.

\section{Genetic structure within the collection}

Overall genetic diversity in the collection was low, with high genetic similarity among accessions. In other words, the frequencies/abundances of polymorphic RAPD fragments in the analysed collection were relatively low, and the distribution pattern of these few polymorphic fragments was very similar for the majority of the accessions, leading to high genetic similarity values. Cluster and multiple correspondence analyses showed the clear separation of $C$. mollis and the non-erect accession 'Yapacaní'. The grouping of the remaining 46 C. argentea accessions differed slightly when based on UPGMA clustering or MCA, indicating that there was no clear pattern within this bulk of accessions. The low genetic differentiation and high genetic similarity among groups show that the low genetic diversity is fairly homogeneously distributed in the collection, without any particular pattern. Also, geographic origin (i.e. distance) apparently did not affect the composition of these groups, since in several instances genetically similar accessions were detected from geographically very distant areas, whereas geographically close accessions often appeared to be genetically very distant in both cluster analysis and MCA. In addition, the genetic variability within accessions was high, with genetic similarities within accessions being only slightly greater than mean similarity among accessions. These findings suggest the existence of a single, widely shared genepool with limited genetic separation among accessions, and indicate the likelihood of extensive outcrossing. These results agree with studies of tropical tree population structures. Tropical tree species appear to have large genepools, with high diversity and little genetic structure, due to extensive outcrossing and geneflow occurring over distances of several kilometres (Schierenbeck et al. 1997).

\section{Mating system}

Among various factors that determine the genetic composition of plant populations, mating system is the most influential. High polymorphism levels of the magnitude observed in the present study for $C$. argentea $(92 \%)$ are reported for outcrossing species, whereas predominantly selfing and/or clonal species generally show much higher proportions (45-80\%) of monomorphic loci (Zhivotovsky, 1999). Similarly, the relatively low differentiation among groups and the high genetic diversity within groups, are characteristic for predominantly outcrossing species, whereas for inbreeding species this relationship tends to be inverted (Nybom, 2004).

Generally, tropical legumes have been considered as predominantly self-pollinated, but there is increasing evidence of cross-pollination in many species, suggesting that some outcrossing may occur in most legume species (Maass and Torres, 1998). Very little is known about the genetics of C. argentea and it is unclear whether $C$. argentea is allogamous or autogamous. While Queiroz et al. (1997) reported from Planaltina, Brazil, the occurrence of outcrossing and suggested a mixed mating system, Bystricky et al. (2006) found C. argentea to be selfincompatible under the conditions of CIAT-Quilichao. Our findings provide further evidence for this. Furthermore, field observations suggest that tripping is involved in fertilization (Andersson et al. 2006a). Pollinators such as the exotic honeybee Apis mellifera, and other bees and bumblebees belonging to the genera Bombus, Centris and Xylocopa (Hymenoptera: Apoidea) have been observed to visit C. argentea flowers loaded with pollen (Queiroz, 1996). Some of these pollinators have been reported to be capable of flight distances of several kilometers thus effecting pollen dispersal between plants at great distances, e.g. the honeybee A. mellifera (Ricketts, 2004) and the carpenter bee Xylocopa fimbriata Fabr. (Gonzalez and Engel, 2004). At CIAT, C. argentea accessions are multiplied in plots that are at least $300 \mathrm{~m}$ distant and hence, isolated from each other to a certain extent (A. Ciprián, CIAT GRU, personal communication 2006). The accessions studied here have not undergone more than two multiplication cycles since seed increase has started. It thus appears that cross-pollination may have occurred also among and within original populations in the wild.

However, we suggest precautions to be taken by genebanks during the regeneration of $C$. argentea accessions to avoid cross-pollination, and the re-consideration of multiplication protocols in order to maintain the genetic integrity of accessions. More detailed studies (e.g. with co-dominant molecular markers) are required to identify the prevailing reproductive strategy of $C$. argentea and to assess the rate and impact of outcrossing in this species. 


\section{Possible duplicates and taxonomic mismatches in the collection}

Although genetically all accessions were significantly different $(P<0.05)$ from each other, a group of five possible duplicate accessions (CIAT 22373, CIAT 22378, CIAT 22380, CIAT 22381, CIAT 22411) was identified, which shared more than $94 \%$ of their banding pattern, differing in three bands only. Re-analysing these accessions with an additional primer or with additional marker types such as AFLP (amplified fragment length polymorphisms) would likely lead to a clearer molecular differentiation between pairs.

Ordination was particularly useful in visualising that the non-erect accession 'Yapacaní', the only germplasm from Bolivia, was genetically almost as distinct from all other $C$. argentea accessions as was $C$. mollis. This, together with its unusual growth habit (climbing vine), suggests that there may be a misclassification of the 'Yapacaní' accession - in spite of the fact that according to the botanical literature (Queiroz and Coradin, 1996), the only Cratylia speciesthat occurs in Bolivia is C. argentea. Botanical specimens from Bolivia and Peru should be re-examined for an eventual taxonomic revision of the genus Cratylia. Also, further germplasm from longitudes higher than $58^{\circ} \mathrm{W}$ (Figure 1) should be collected and its genetic diversity analyzed in support of taxonomic re-considerations.

With respect to accessions CIAT 18516 and CIAT 18668 which form the commercial cultivar, it was striking that CIAT 18668 was genetically very different from CIAT 18516 as well as from most other C. argentea accessions (Figure 3). In agronomic evaluations, however, these two accessions were not only very similar regarding morphological characteristics and forage quality (Andersson et al. 2006a), but also regarding consistently high DM production in different environments. The fact that in terms of RAPD variation these accessions appear to be very distinct might be an indicator of the neutral (i.e. non-functional) nature of the polymorphisms detected by this molecular technique. Furthermore, it is unknown to which extent the agronomic traits above are influenced by the environment. RAPD markers therefore are not an adequate tool for predicting or explaining agronomic characteristics. These contradictions probably could be solved either using morphological characters that are less sensitive to environmental variation, or performing more thorough examinations with more sophisticated techniques (e.g. ISSR-PCR).

\section{Acknowledgments}

We express our gratitude to two anonymous referees designated by CIAT for helpful comments on an earlier version of this draft. Thanks are also due to J. Tohme from the CIAT Biotechnology Unit for facilitating laboratory infrastructure. The study is part of a project financially supported by the German Academic Exchange Service (DAAD) and the Eiselen-Stiftung Ulm, Germany.

\section{References}

ANDERSSON, Meike S.; PETERS, Michael; SCHULTZEKRAFT, Rainer; FRANCO, Luis-Horácio and LASCANO, Carlos E. Phenological, agronomic and forage quality diversity among germplasm accessions of the tropical legume shrub Cratylia argentea. Journal of Agricultural Science, June 2006a, vol. 144, no. 3, p. 237-248.

ANDERSSON, Meike S.; PETERS, Michael; SCHULTZEKRAFT, Rainer; GALLEGO, Gerardo and DUQUE, Myriam C. Molecular characterization of a collection of the tropical multipurpose shrub legume Flemingia macrophylla. Agroforestry Systems, November 2006b, vol. 68 , no. 3 , p. $231-245$.

ARGEL, Pedro J. and LASCANO, Carlos E. Cratylia argentea (Desvaux) O. Kuntze: una nueva leguminosa arbustiva para suelos ácidos en zonas subhúmedas tropicales. Pasturas Tropicales, April 1998, vol. 20, no. 1, p. 37-43.

BYSTRICKY, Maria; PETERS, Michael; ESCOBAR, Germán; SCHULTZE-KRAFT, Rainer and FRANCO, Luis Horacio. Floral biology of Cratylia argentea - First results of a study in Colombia. In: Deutscher Tropentag 2006: Prosperity and poverty in a globalized world - challenges for agricultural research $\left(11^{\text {th }}-13^{\text {th }}\right.$ October, 2006, University of Bonn, Germany). Book of abstracts. p. 349.

CHENUIL, Anne. Choosing the right molecular genetic markers for studying biodiversity: from molecular evolution to practical aspects. Genetica, May 2006, vol. 127 , no. 1-3, p. 101-120.

GONZÁLEZ, Victor H. and ENGEL, Michael S. The tropical Andean bee fauna (Insecta: Hymenoptera: Apoidea), with examples from Colombia. Entomologische Abhandlungen, June 2004, vol. 62, no. 1, p. 65-75.

JONES, Neil; OUGHAM, Helen and THOMAS, Howard. Markers and mapping: we are all geneticists now. New Phytologist, September 1997, vol. 137, no. 1, p. 165-177.

LASCANO, Carlos E.; RINCÓN, Álvaro; PLAZAS, Camilo; ÁVILA, Patricia; BUENO, Guillermo and ARGEL, Pedro J. Cultivar Veranera (Cratylia argentea (Desvaux) O. Kuntze): leguminosa arbustiva de usos múltiples para zonas con períodos prolongados de sequía en Colombia. Cali, Colombia, Corporación Colombiana de Investigación Agropecuaria (CORPOICA), International Center for Tropical Agriculture (CIAT), 2002. 28 p. Available from Internet: http://www.ciat.cgiar.org/forrajes/pdf/cratyllia_argentea_cv _veranera.pdf. 
MAASS, Brigitte L. and TORRES, Alba M. Off-types indicate natural outcrossing in five tropical forage legumes in Colombia. Tropical Grasslands, June 1998, vol. 32, no. 2, p. 124-130.

NEI, Masatoshi and LI, Wen-Hsiung. Mathematical model for studying genetic variation in terms of restriction endonucleases. Proceedings of the National Academy of Sciences of the United States of America, October 1979, vol. 76, no. 10, p. 5269-5273.

NYBOM, Hilde. Comparison of different nuclear DNA markers for estimating intraspecific genetic diversity in plants. Molecular Ecology, May 2004, vol. 13, no. 5, p. 1143-1155.

PARKER, Patricia G.; SNOW, Allison A.; SCHUG, Malcolm D.; BOOTON, Gregory C. and FUERST, Paul A. What molecules can tell us about populations: choosing and using a molecular marker. Ecology, March 1998, vol. 79, no. 2, p. 361-382.

PIZARRO, Esteban A.; CARVALHO, Marcelo A. and RAMOS, Allan K.B. Introducción y evaluación de leguminosas forrajeras arbustivas en el Cerrado brasileño. In: PIZARRO, Esteban A. and CORADIN, Lídio eds. Potencial del género Cratylia como leguminosa forrajera. Memorias del taller de trabajo realizado el 19 y 20 de julio 1995, Brasilia, DF, Brasil. Documento de Trabajo No. 158, Cali, Colombia, International Center for Tropical Agriculture (CIAT), 1996, p. 40-49. Available from Internet:

http://www.ciat.cgiar.org/forrajes/pdf/Cratylia_02(783).pdf.

QUEIROZ, Luciano P. de. Pollination ecology studies in Cratylia Mart. ex Benth. (Leguminosae: Papilionoideae) and its taxonomic and evolutionary implications. Sitientibus (UEFS), 1996, vol. 15, p. 119-131.

QUEIROZ, Luciano P. de and CORADIN, Lídio. Biogeografia de Cratylia e areas prioritárias para coleta. In: PIZARRO, Esteban A. and CORADIN, Lídio eds. Potencial del género Cratylia como leguminosa forrajera. Memorias del taller de trabajo realizado el 19 y 20 de julio 1995, Brasilia, DF, Brasil. Documento de Trabajo No. 158, Cali, Colombia, International Center for Tropical Agriculture (CIAT), 1996, p. 1-28. Available from Internet: http://www.ciat.cgiar.org/forrajes/pdf/Cratylia_02(783).pdf

QUEIROZ, Luciano P. de; SILVA, Mario M. da; RAMOS, Allan K.B. and PIZARRO, Esteban A. Estudos reprodutivos em Cratylia argentea (Desv.) O. Kuntze e Cratylia mollis Mart. ex Benth. (LeguminosaePapilionoideae). Pasturas Tropicales, December 1997, vol. 19, no. 3, p. 20-23.
RICKETTS, Taylor H. Tropical forest fragments enhance pollinator activity in nearby coffee crops. Conservation Biology, October 2004, vol. 18, no. 5, p. 1262-1271.

SCHIERENBECK, Kristina A.; SKUPSKI, Marian P.; LIEBERMAN, Diana and LIEBERMAN, Milton. Population structure and genetic diversity in four tropical tree species in Costa Rica. Molecular Ecology, February 1997, vol. 6, no. 2, p. 137-144.

SCHULTZE-KRAFT, Rainer. Leguminous forage shrubs for acid soils in the tropics. In: ELGERSMA, Anjo; STRUIK, Paul C. and MAESEN, Jos L.G. van der eds. Grassland Science in Perspective. Wageningen Agricultural University Papers 96-4, 1996, p. 67-81.

TESSIER, Cécile; DAVID, Jaques L.; THIS, Patrice; BOURSIQUOT, Jean-Michel and CHARRIER, André. Optimization of the choice of molecular markers for varietal identification in Vitis vinifera $\mathrm{L}$. Theoretical and Applied Genetics, January 1999, vol. 98, no. 1, p. 171-177.

ZHIVOTOVSKY, Lev A. Estimating population structure in diploids with multilocus dominant DNA markers. Molecular Ecology, June 1999, vol. 8, no. 6, p. 907-913. 
APPENDIX

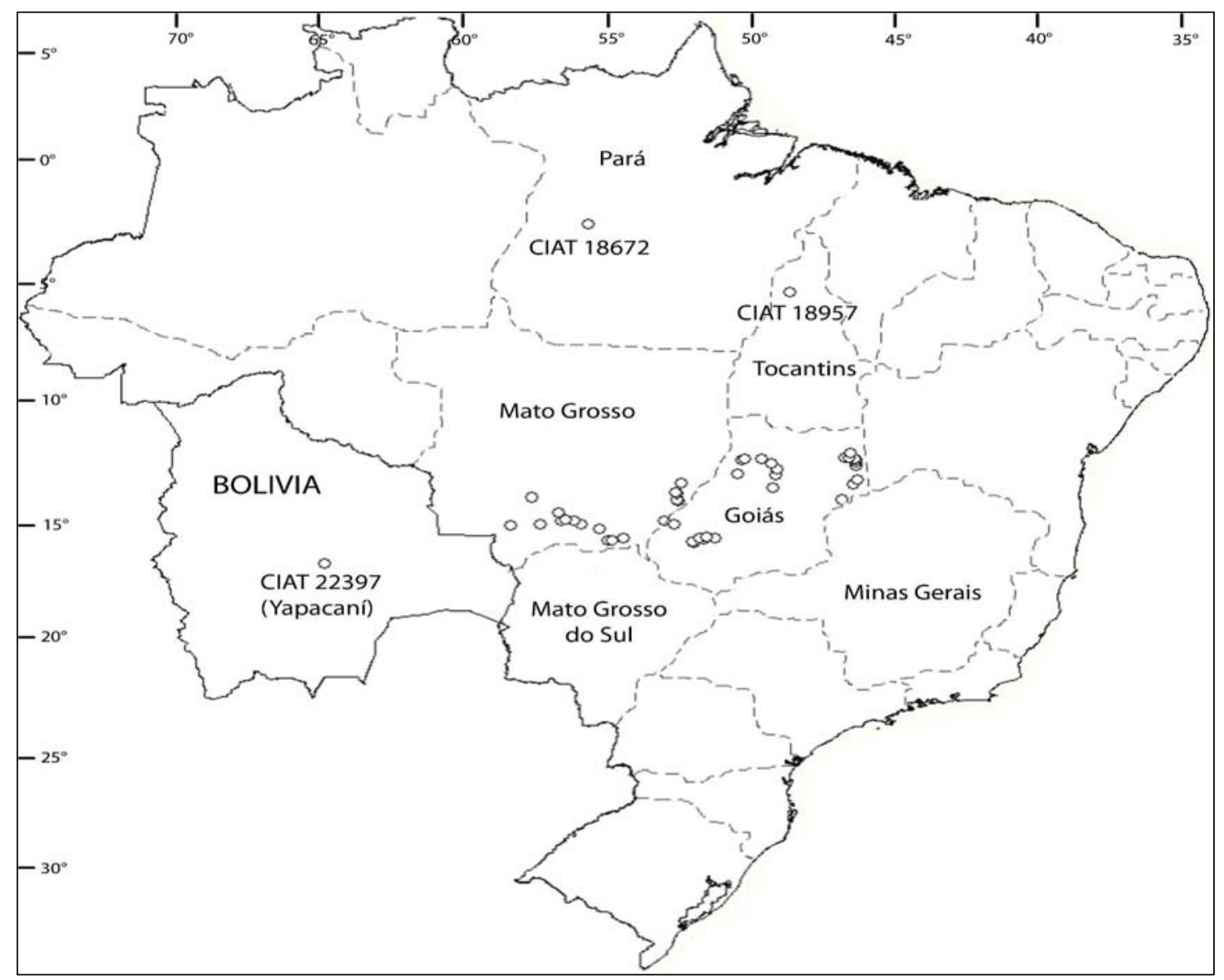

Figure 1. Geographical distribution of the 47 Cratylia argentea accessions used in this study. The accessions were originally collected in the states Mato Grosso, Goiás, Tocantins and Pará in Brazil, and in Bolivia. 


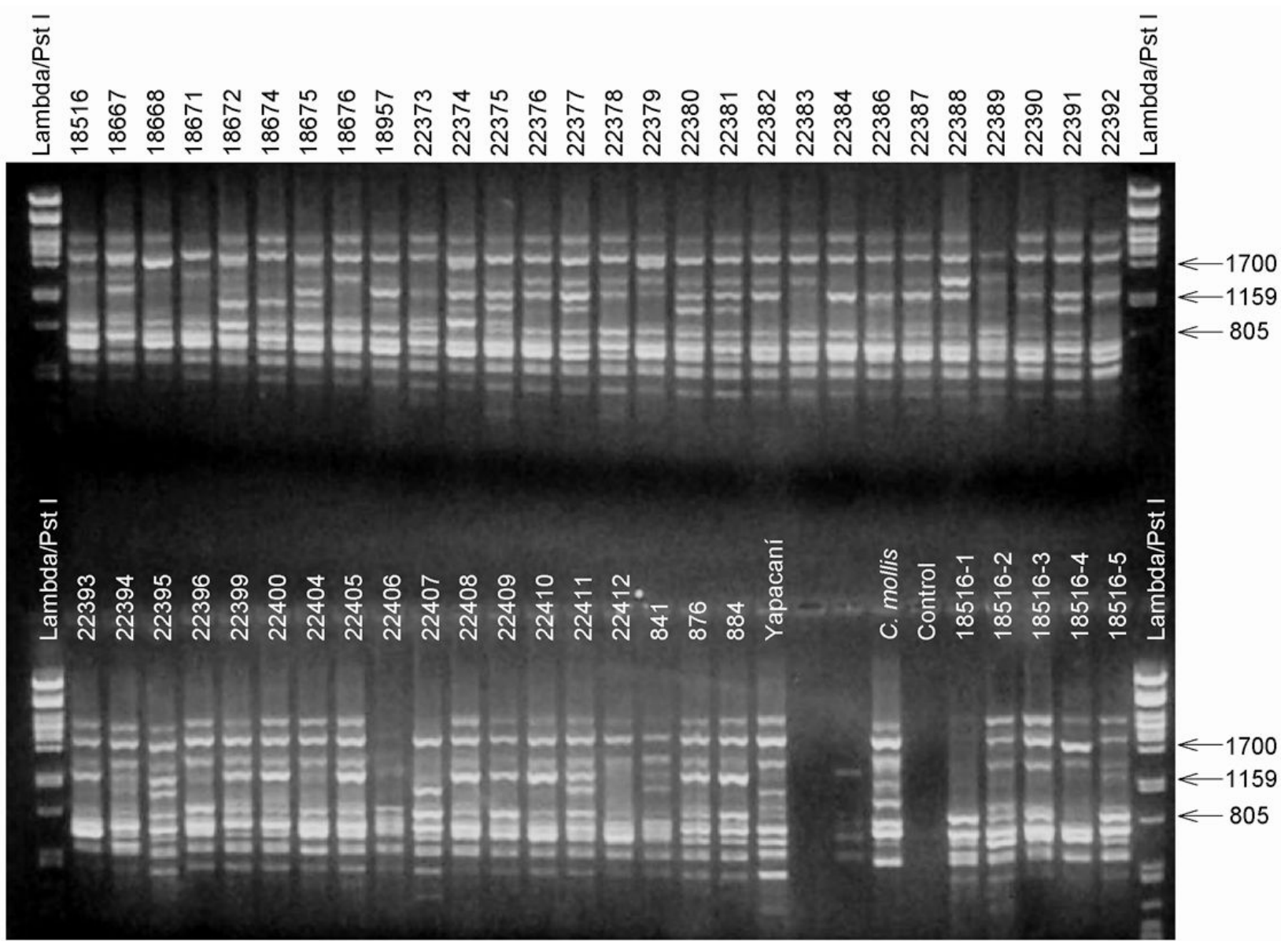

Figure 2. RAPD profile obtained using primer OPD15 for 47 Cratylia argentea accessions, $C$. mollis, one DNAfree control, and five samples of different individuals of accession CIAT 18516 for the assessment of withinaccession variability. Size markers ( $\lambda$-DNA/Pstl, Invitrogen, USA) for assessing base pair lengths are shown in the first and last lanes. 


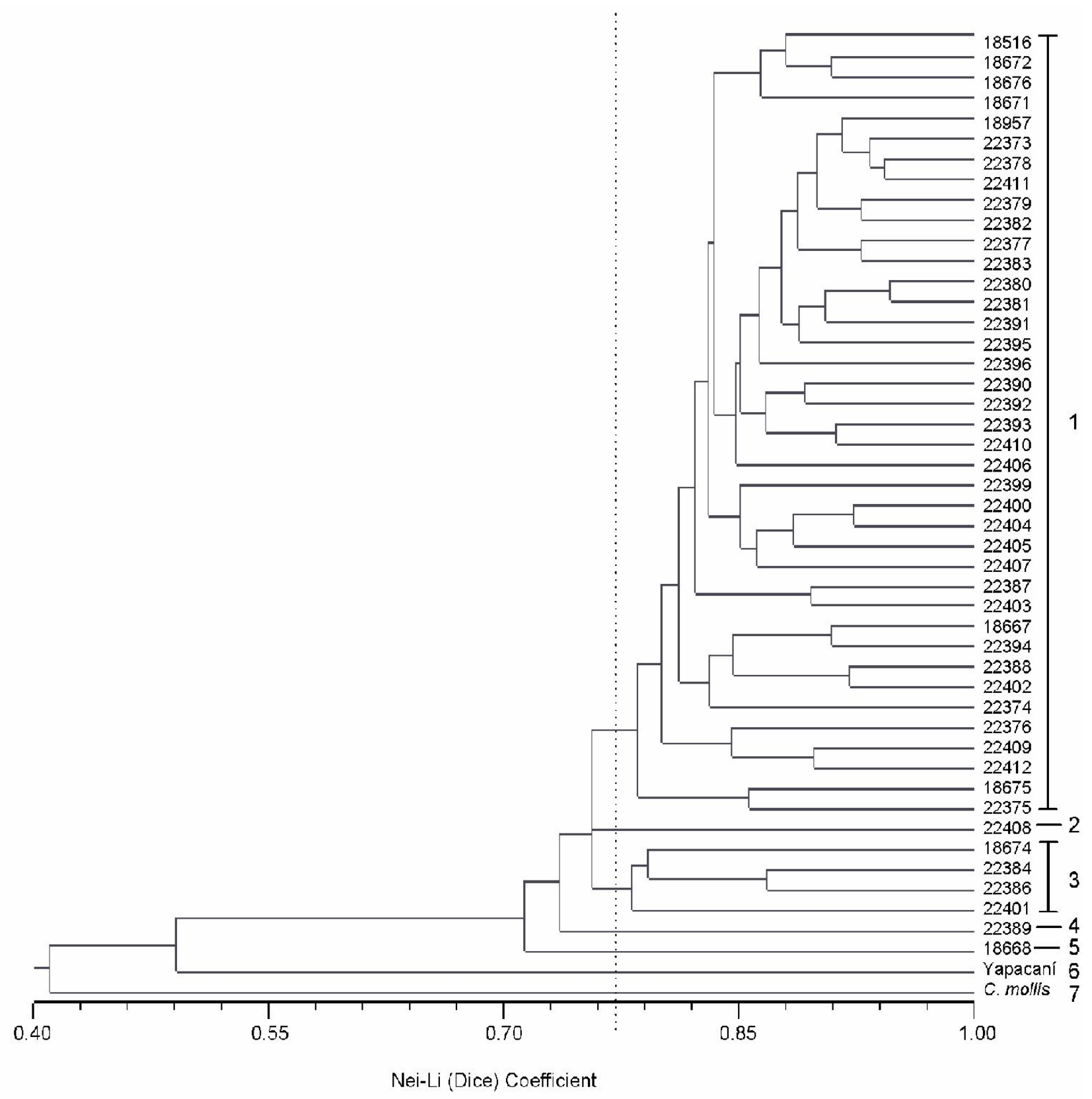

Figure 3. Grouping of 47 Cratylia argentea accessions and a C. mollis reference accession, using UPGMA. Genetic distances are according to Nei and Li based on RAPD markers. Clusters were analysed at the 0.77 similarity level (dotted line). 


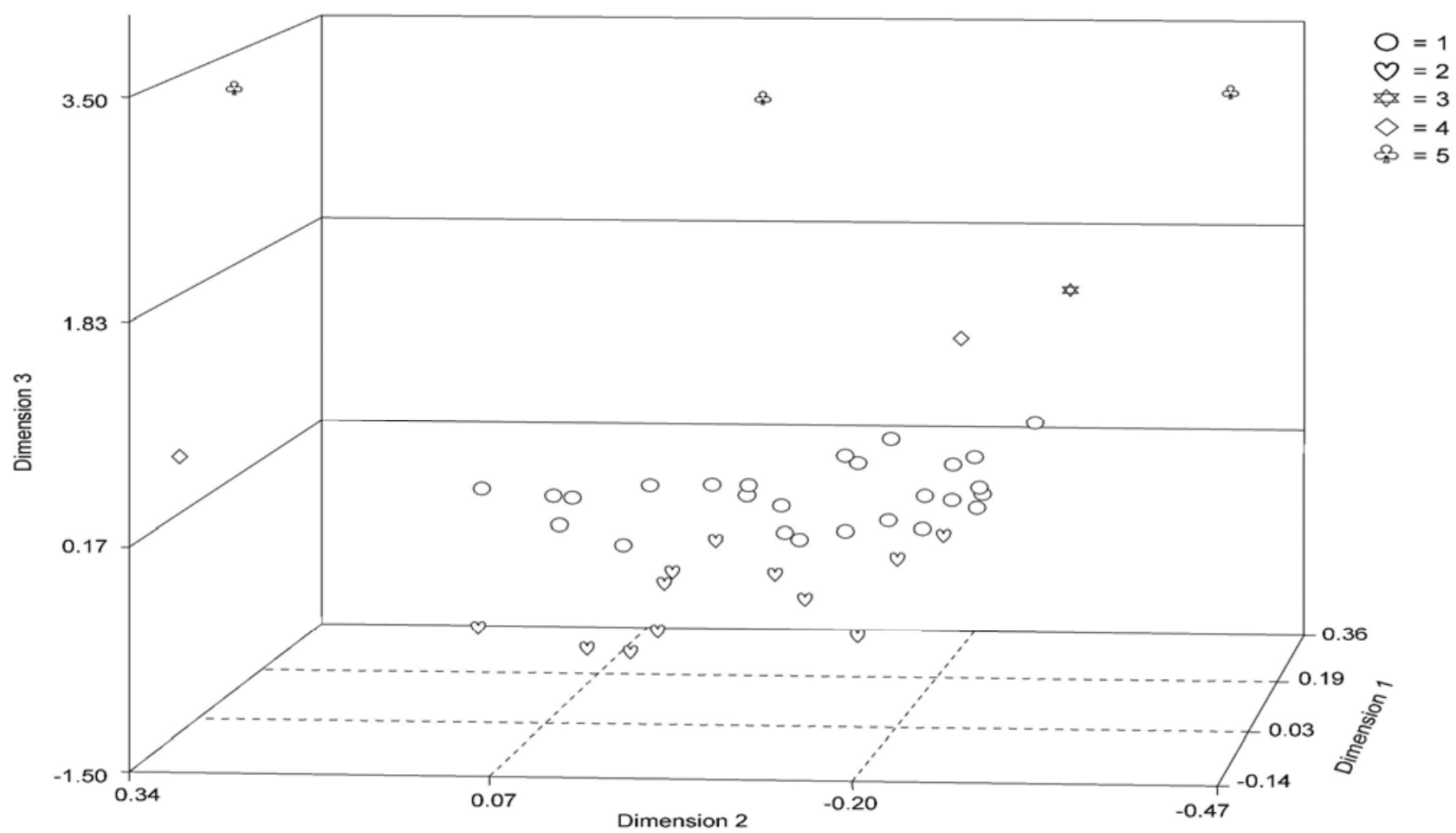

Figure 4. Three-dimensional representation of five groups derived from MCA of RAPDs among 46 Cratylia argentea accessions (without 'Yapacaní'). 
Table 1. Origin of the Cratylia argentea accessions used in the present study (Queiroz and Coradin, 1996; CIAT Tropical Forages Database and G.P. da Silva, Embrapa Recursos Genéticos e Biotecnologia [personal communication]).

\begin{tabular}{|c|c|c|c|c|c|c|}
\hline $\begin{array}{l}\text { CIAT } \\
\text { No. }\end{array}$ & $\begin{array}{c}\text { EMBRAPA } \\
\text { No. }\end{array}$ & State & Latitude & Longitude & $\begin{array}{l}\text { Altitude } \\
\text { (masl) }\end{array}$ & $\begin{array}{l}\text { Year of } \\
\text { collection }\end{array}$ \\
\hline 18516 & 000167 & Goiás & $13^{\circ} 22^{\prime} \mathrm{S}$ & $46^{\circ} 25^{\prime} W$ & 800 & pre-1980 \\
\hline 18667 & 000027 & Mato Grosso & $15^{\circ} 43^{\prime} \mathrm{S}$ & $55^{\circ} 43^{\prime} \mathrm{W}$ & 455 & 1984 \\
\hline 18668 & 000035 & Mato Grosso & $15^{\circ} 22^{\prime} \mathrm{S}$ & $56^{\circ} 13^{\prime} W$ & 175 & 1984 \\
\hline 18671 & 000060 & Mato Grosso & $14^{\circ} 46^{\prime} \mathrm{S}$ & $57^{\circ} 05^{\prime} \mathrm{W}$ & 230 & 1984 \\
\hline 18672 & 000086 & Pará & $03^{\circ} 45^{\prime} \mathrm{S}$ & $55^{\circ} 14^{\prime} \mathrm{W}$ & 140 & 1984 \\
\hline 18674 & 000116 & Mato Grosso & $14^{\circ} 38^{\prime} \mathrm{S}$ & $52^{\circ} 22^{\prime} W$ & 320 & 1984 \\
\hline 18675 & 000124 & Mato Grosso & $14^{\circ} 54^{\prime} \mathrm{S}$ & $52^{\circ} 17^{\prime} \mathrm{W}$ & 380 & 1984 \\
\hline 18676 & 000132 & Goiás & $16^{\circ} 21^{\prime} \mathrm{S}$ & $51^{\circ} 20^{\prime} \mathrm{W}$ & 450 & 1984 \\
\hline 18957 & 000175 & Tocantins & $06^{\circ} 30^{\prime} \mathrm{S}$ & $48^{\circ} 37^{\prime} W$ & 350 & pre-1980 \\
\hline 22373 & 000591 & Goiás & $14^{\circ} 05^{\prime} \mathrm{S}$ & $46^{\circ} 23^{\prime} W$ & 780 & 1995 \\
\hline 22374 & 000612 & Goiás & $13^{\circ} 16^{\prime} \mathrm{S}$ & $46^{\circ} 25^{\prime} W$ & 660 & 1995 \\
\hline 22375 & 000639 & Goiás & $13^{\circ} 01^{\prime} \mathrm{S}$ & $46^{\circ} 36^{\prime} W$ & 620 & 1995 \\
\hline 22376 & 000655 & Goiás & $14^{\circ} 23^{\prime} \mathrm{S}$ & $49^{\circ} 09^{\prime} \mathrm{W}$ & 550 & 1995 \\
\hline 22377 & 000663 & Goiás & $13^{\circ} 54^{\prime} \mathrm{S}$ & $49^{\circ} 03^{\prime} \mathrm{W}$ & 510 & 1995 \\
\hline 22378 & 000671 & Goiás & $13^{\circ} 37^{\prime} \mathrm{S}$ & $49^{\circ} 02^{\prime} \mathrm{W}$ & 390 & 1995 \\
\hline 22379 & 000680 & Goiás & $13^{\circ} 21^{\prime} \mathrm{S}$ & $47^{\circ} 07^{\prime} \mathrm{W}$ & 380 & 1995 \\
\hline 22380 & 000698 & Goiás & $13^{\circ} 14^{\prime} \mathrm{S}$ & $49^{\circ} 28^{\prime} W$ & 340 & 1995 \\
\hline 22381 & 000701 & Goiás & $13^{\circ} 14^{\prime} \mathrm{S}$ & $50^{\circ} 40^{\prime} \mathrm{W}$ & 360 & 1995 \\
\hline 22382 & 000710 & Goiás & $13^{\circ} 17^{\prime} \mathrm{S}$ & $50^{\circ} 12^{\prime} \mathrm{W}$ & 330 & 1995 \\
\hline 22383 & 000728 & Goiás & $13^{\circ} 51^{\prime} \mathrm{S}$ & $50^{\circ} 20^{\prime} \mathrm{W}$ & 300 & 1998 \\
\hline 22384 & 000736 & Mato Grosso & $14^{\circ} 14^{\prime} \mathrm{S}$ & $52^{\circ} 10^{\prime} \mathrm{W}$ & 360 & 1995 \\
\hline 22386 & 000752 & Mato Grosso & $14^{\circ} 34^{\prime} \mathrm{S}$ & $52^{\circ} 21^{\prime} \mathrm{W}$ & 320 & 1995 \\
\hline 22387 & 000761 & Mato Grosso & $15^{\circ} 50^{\prime} \mathrm{S}$ & $52^{\circ} 25^{\prime} \mathrm{W}$ & 370 & 1995 \\
\hline 22388 & 000787 & Mato Grosso & $16^{\circ} 23^{\prime} \mathrm{S}$ & $54^{\circ} 01^{\prime} \mathrm{W}$ & 330 & 1995 \\
\hline 22389 & 000795 & Mato Grosso & $16^{\circ} 26^{\prime} S$ & $54^{\circ} 19^{\prime} \mathrm{W}$ & 400 & 1995 \\
\hline 22390 & 000809 & Mato Grosso & $16^{\circ} 01^{\prime} \mathrm{S}$ & $54^{\circ} 55^{\prime} \mathrm{W}$ & 300 & 1995 \\
\hline 22391 & 000817 & Mato Grosso & $15^{\circ} 49^{\prime} \mathrm{S}$ & $55^{\circ} 30^{\prime} \mathrm{W}$ & 400 & 1995 \\
\hline 22392 & 000825 & Mato Grosso & $15^{\circ} 58^{\prime} \mathrm{S}$ & $55^{\circ} 00^{\prime} \mathrm{W}$ & 240 & 1995 \\
\hline 22393 & 000833 & Mato Grosso & $15^{\circ} 42^{\prime} \mathrm{S}$ & $56^{\circ} 42^{\prime} \mathrm{W}$ & 210 & 1995 \\
\hline 22394 & 000868 & Mato Grosso & $15^{\circ} 52^{\prime} \mathrm{S}$ & $57^{\circ} 49^{\prime} \mathrm{W}$ & 200 & 1995 \\
\hline 22395 & 000892 & Goiás & $16^{\circ} 25^{\prime} \mathrm{S}$ & $51^{\circ} 35^{\prime} \mathrm{W}$ & 460 & 1995 \\
\hline 22396 & 000906 & Goiás & $16^{\circ} 32^{\prime} \mathrm{S}$ & $51^{\circ} 03^{\prime} \mathrm{W}$ & 510 & 1995 \\
\hline 22397 & 'Yapacaní' & Bolivia, Santa Cruz & $17^{\circ} 25^{\prime} \mathrm{S}$ & $63^{\circ} 56^{\prime} \mathrm{W}$ & 350 & 1998 \\
\hline 22399 & 000604 & Goiás & $14^{\circ} 30^{\prime} \mathrm{S}$ & $46^{\circ} 24^{\prime} \mathrm{W}$ & 650 & 1995 \\
\hline 22400 & 000621 & Goiás & $13^{\circ} 10^{\prime} \mathrm{S}$ & $46^{\circ} 40^{\prime} \mathrm{W}$ & 660 & 1995 \\
\hline 22401 & 000841 & Mato Grosso & $15^{\circ} 51^{\prime} \mathrm{S}$ & $56^{\circ} 49^{\prime} \mathrm{W}$ & 360 & 1995 \\
\hline 22402 & 000876 & Mato Grosso & $16^{\circ} 30^{\prime} \mathrm{S}$ & $54^{\circ} 36^{\prime} \mathrm{W}$ & 270 & 1995 \\
\hline 22403 & 000884 & Mato Grosso & $16^{\circ} 34^{\prime} \mathrm{S}$ & $51^{\circ} 45^{\prime} \mathrm{W}$ & 600 & 1995 \\
\hline 22404 & 000191 & Goiás & $13^{\circ} 01^{\prime} \mathrm{S}$ & $56^{\circ} 37^{\prime} \mathrm{W}$ & 650 & 1993 \\
\hline 22405 & 000213 & Goiás & $13^{\circ} 15^{\prime} \mathrm{S}$ & $46^{\circ} 28^{\prime} \mathrm{W}$ & 700 & 1993 \\
\hline 22406 & 000221 & Goiás & $14^{\circ} 15^{\prime} \mathrm{S}$ & $46^{\circ} 30^{\prime} \mathrm{W}$ & 780 & 1993 \\
\hline 22407 & 000514 & Goiás & $14^{\circ} 54^{\prime} \mathrm{S}$ & $46^{\circ} 56^{\prime} \mathrm{W}$ & 500 & 1995 \\
\hline 22408 & 000540 & Mato Grosso & $14^{\circ} 06^{\prime} \mathrm{S}$ & $46^{\circ} 25^{\prime} \mathrm{W}$ & 810 & 1995 \\
\hline 22409 & 000566 & Goiás & $13^{\circ} 27^{\prime} \mathrm{S}$ & $46^{\circ} 22^{\prime} \mathrm{W}$ & 540 & 1995 \\
\hline 22410 & 000574 & Goiás & $13^{\circ} 17^{\prime} \mathrm{S}$ & $46^{\circ} 25^{\prime} \mathrm{W}$ & 660 & 1995 \\
\hline 22411 & 000647 & Goiás & $15^{\circ} 12^{\prime} \mathrm{S}$ & $46^{\circ} 47^{\prime} \mathrm{W}$ & 550 & 1995 \\
\hline 22412 & 000779 & Mato Grosso & $15^{\circ} 42^{\prime} \mathrm{S}$ & $52^{\circ} 43^{\prime} \mathrm{W}$ & 400 & 1995 \\
\hline
\end{tabular}


Table 2. Oligonucleotide primers employed in RAPD analysis of Cratylia argentea, their sequence, number of polymorphic $(P)$ and monomorphic $(M)$ bands obtained, percentage of polymorphic bands (\% PB), and discriminatory power $\left(D_{L}\right)$.

\begin{tabular}{|c|c|c|c|c|c|c|}
\hline \multirow{3}{*}{$\begin{array}{l}\text { Primer } \\
\text { code }\end{array}$} & \multirow{3}{*}{$\begin{array}{c}\text { Sequence } \\
\left.\text { (5' to } 3^{\prime}\right)\end{array}$} & \multicolumn{4}{|c|}{ Number of bands } & \multirow{3}{*}{$D_{\mathrm{L}}$} \\
\hline & & \multicolumn{2}{|c|}{ (including C. mollis) } & \multicolumn{2}{|c|}{ (only C. argentea) } & \\
\hline & & $\mathbf{P}$ & $M$ & $\mathbf{P}$ & M & \\
\hline OPD 15 & CATCCGTGCT & 9 & 1 & 7 & 1 & 0.903 \\
\hline OPG 12 & CAGCTCACGA & 16 & 1 & 11 & 1 & 0.942 \\
\hline OPI 07 & CAGCGACAAG & 16 & 1 & 12 & 2 & 0.755 \\
\hline OPJ 06 & TCGTTCCGCA & 13 & 0 & 13 & 0 & 0.898 \\
\hline OPJ 07 & CCTCTCGACA & 8 & 0 & 8 & 0 & 0.862 \\
\hline OPJ 12 & GTCCCGTGGT & 6 & 1 & 5 & 1 & 0.615 \\
\hline Sum & & 68 & 4 & 56 & 5 & \\
\hline Total & & \multicolumn{2}{|c|}{72} & \multicolumn{2}{|c|}{61} & \\
\hline PB (\%) & & \multicolumn{2}{|c|}{94.4} & \multicolumn{2}{|c|}{91.8} & \\
\hline
\end{tabular}

Table 3. Nei estimates of genetic diversity (heterogeneity) among groups of Cratylia argentea.

\begin{tabular}{|l|c|c|c|}
\hline \multicolumn{1}{|c|}{ Group } & $\mathbf{n}$ & $\boldsymbol{H}_{\mathbf{i ( 1 - 7 )}}$ & $\boldsymbol{H}_{\mathbf{i ( 1 - 5 )}}$ \\
\hline 1 & 28 & 0.128 & 0.128 \\
\hline 2 & 12 & 0.126 & 0.126 \\
\hline 3 & 1 & 0.0 & 0.0 \\
\hline 4 & 2 & 0.101 & 0.101 \\
\hline 5 & 3 & 0.120 & 0.120 \\
\hline 6 ('Yapacani') & 1 & 0.0 & - \\
\hline 7 (C. mollis) & 1 & 0.0 & - \\
\hline HS & & 0.118 & 0.123 \\
\hline HT & & 0.169 & 0.145 \\
\hline GST & & 0.302 & 0.152 \\
\hline
\end{tabular}

$n$ : number of accessions.

$H_{i}$ : genetic diversity within each group.

$H_{s}$ : average genetic diversity within groups.

$H_{T}$ : total genetic diversity.

$G_{S T}$ : coefficient of genetic differentiation (proportion of total genetic diversity found among groups). 
Table 4. Average genetic similarity (GS) values between (above diagonal) and within (diagonal) groups of Cratylia argentea germplasm, the non-erect accession 'Yapacaní' and the $C$. mollis reference accession, based on all pairwise similarities between accessions according to molecular marker information (RAPDs).

\begin{tabular}{|c|c|c|c|c|c|c|c|c|c|}
\hline \multirow{2}{*}{ Group } & \multirow{2}{*}{$n$} & \multicolumn{6}{|c|}{ Cratylia argentea } & \multirow{2}{*}{ 'Yapacaní' } & \multirow{2}{*}{ C. mollis } \\
\hline & & 1 & 2 & 3 & 4 & 5 & Total & & \\
\hline 1 & 28 & 0.825 & 0.814 & 0.769 & 0.774 & 0.759 & & 0.487 & 0.413 \\
\hline 2 & 12 & & 0.839 & 0.720 & 0.764 & 0.721 & & 0.515 & 0.404 \\
\hline 3 & 1 & & & 1.000 & 0.757 & 0.754 & & 0.426 & 0.433 \\
\hline 4 & 2 & & & & 0.717 & 0.748 & & 0.479 & 0.400 \\
\hline 5 & 3 & & & & & 0.757 & & 0.457 & 0.388 \\
\hline C. argentea & 46 & & & & & & 0.805 & & \\
\hline 'Yapacaní' & 1 & & & & & & & 1.000 & 0.444 \\
\hline C. mollis & 1 & & & & & & & & 1.000 \\
\hline Total & 48 & & & & & & & & 0.776 \\
\hline
\end{tabular}

$n$ : number of accessions.

Table 5. Genetic similarity among (above diagonal) and within (diagonal) five Cratylia argentea accessions, based on all pairwise similarities between individuals according to molecular marker information (RAPDs).

\begin{tabular}{|l|c|c|c|c|c|c|c|}
\hline \multicolumn{1}{|c|}{ CIAT No. } & $\boldsymbol{n}$ & $\mathbf{1 8 5 1 6}$ & $\mathbf{1 8 6 6 8}$ & $\mathbf{1 8 6 7 4}$ & $\mathbf{2 2 4 0 8}$ & $\mathbf{2 2 4 0 9}$ & Total \\
\hline 18516 & 10 & 0.730 & 0.704 & 0.724 & 0.669 & 0.735 & \\
\hline 18668 & 10 & & 0.763 & 0.727 & 0.667 & 0.719 & \\
\hline 18674 & 10 & & & 0.782 & 0.692 & 0.753 & \\
\hline 22408 & 10 & & & & 0.737 & 0.710 & \\
\hline 22409 & 10 & & & & & 0.800 & \\
\hline Total & 50 & & & & & & 0.720 \\
\hline
\end{tabular}

$n$ : number of individuals per accession. 